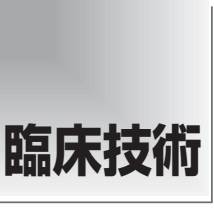

論文受付

2016 年 1 月 13 日

論文受理

2016 年 5 月 19 日

Code No. 300

\section{${ }^{123} \mathrm{I}-\mathrm{FP}-\mathrm{CIT}$ SPECT における画像再構成方法が 定量性と診断能に与える影響}

\author{
亀井山弘晃 ${ }^{1}$ 松友紀和 ${ }^{2}$ 長木昭男 ${ }^{1}$ 山尾房枝 ${ }^{3}$ \\ ${ }^{1}$ 倉敷中央病院放射線技術部 \\ 2 杏林大学保健学部診療放射線技術学科 \\ ${ }^{3}$ 倉敷中央病院神経内科
}

\section{緒 言}

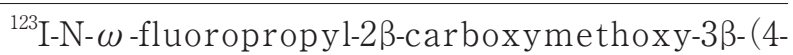
iodophenyl) nortropane ( ${ }^{123} \mathrm{I}$-FP-CIT) single photon emission computed tomography (SPECT) を用いた線 条体イメージングはパーキンソン病やレビー小体型認 知症の鑑別診断に有用とされている ${ }^{1 \sim 3)}$. また, ${ }^{123} \mathrm{I}-$ FP-CITの線条体に対する特異的結合を定量的に表し た specific binding ratio(SBR)は, 鑑別診断を行う際
の客観的診断指標のひとつとして用いられている ${ }^{4,5)}$.

${ }^{123}$ I-FP-CIT-SPECT の画像再構成方法について欧米 のガイドラインでは, フィルタ補正逆投影(filtered back projection: FBP) 法や逐次近似画像再構成の一種 であるサブセット化期待值最大化 (ordered subsets expectation maximization: OSEM) 法を使用し, 減弱補 正 (attenuation correction: AC) を行うことが推奨され ており ${ }^{6,7)}$, 国内ガイドラインでは散乱線補正 (scatter

\title{
Effect of Reconstruction Strategies for the Quantification and Diagnostic Accuracy of ${ }^{123}$ I-FP-CIT SPECT
}

\author{
Hiroaki Kameiyama, ${ }^{1 *}$ Norikazu Matsutomo, ${ }^{2}$ Akio Nagaki, ${ }^{1}$ and Fusae Yamao ${ }^{3}$ \\ ${ }^{1}$ Department of Radiological Technology, Kurashiki Central Hospital \\ ${ }^{2}$ Department of Medical Radiological Technology, Faculty of Health Sciences, Kyorin University \\ ${ }^{3}$ Department of Neurology, Kurashiki Central Hospital
}

Received January 13, 2016; Revision accepted May 19, 2016

Code No. 300

\section{Summary}

Purpose: This study evaluates the effect of reconstruction strategies for the quantification and diagnostic accuracy of ${ }^{123}$ I-FP-CIT SPECT. Methods: We evaluated the quantification of ${ }^{123}$ I-FP-CIT SPECT obtained by several combinations of reconstruction using the striatal phantom. The phantom images were reconstructed using FBP and OSEM with/without attenuation correction (AC) and scatter correction (SC). We calculated the specific binding ratio (SBR) using volume of interest (VOI) analysis on each reconstructed images. For the clinical study, 40 patients who underwent ${ }^{123}$ I-FP-CIT SPECT were selected. We grouped the patients into the normal binding group and decreased binding group according to their clinical diagnosis. The clinical images were reconstructed under the same conditions as the phantom study. The SBRs were calculated, and a receiver operating characteristic (ROC) analysis was performed to evaluate the diagnostic accuracy. Results: The SBRs with AC and SC significantly increased compared with no corrections. In the clinical study, although ROC analysis showed no significant difference in the all combinations of reconstruction, the area under the curve using SC and AC tended to be higher than that obtained by other reconstruction. Conclusions: Quantification of ${ }^{123}$ I-FP-CIT SPECT was affected by reconstruction strategies. In addition, both the AC and SC improved the diagnostic accuracy of ${ }^{123}$ I-FP-CIT SPECT. Our results suggest that both the AC and SC are recommended for the improving the quantification and diagnostic accuracy in ${ }^{123}$ I-FP-CIT SPECT.

Key words: receiver operating characteristic analysis, ${ }^{123}$ I-FP-CIT SPECT, reconstruction, image correction 
correction: SC)の使用も推奨されている4). また, 近年 では線源とコリメータの距離による空間分解能の劣化 を補正するコリメー夕開口補正を構造した OSEM 法 も使用されている。このように SPECT の画像再構成 にはさまざまなパラメータが存在し，これらの画像再 構成方法の組み合わせによって ${ }^{123}$ I-FP-CIT SPECT の 画質や定量性は大きく変化することが報告されてい $る^{8-10)}$. Koch らは OSEM 法を用いることで, FBP 法 と比較して画質と定量性が向上すると報告してい る8. また, BienkiewiczらはFBP 法と OSEM 法にそ れぞれ異なる AC を用いることで，定量性が大きく変 化することを報告している ${ }^{9)}$. このように画像再構成 方法と定量性に関する報告は海外論文に見受けられる が, 画像再構成方法が ${ }^{123}$ I-FP-CIT SPECT の定量性と 診断能に与える影響について, より詳細な検討が必要 と考える.また, SBRは正常值と異常值の鑑別を行う 上で重要な指標となることから，画像再構成方法が SBRに与える影響を明らかにし, 画像再構成方法ごと に適切なカットオフ値を規定することは重要な意味を 持つと考えられる.

本研究の目的は, ${ }^{123}$ I-FP-CIT SPECT における画像 再構成方法が定量性と診断能に与える影響を明らかに し，最適な画像再構成方法を確立することである，わ れわれは, 画像再構成方法として FBP 法とコリメー 夕開口補正を構造した OSEM $\left(\mathrm{OSEM}_{\mathrm{RR}}\right)$ 法, 補正方法 に $\mathrm{AC}, \mathrm{SC}$ を使用し, これらの組合せによって画像再 構成を行ったファントムデータを用いて SBR を評価 した，更に臨床デー夕を用いて画像再構成方法と診断 能との関係を $\mathrm{ROC}$ 解析から評価した。

\section{1. 方 法}

\section{1-1 使用機器および収集処理条件}

SPECT/CT 装置は低中エネルギー沉用型コリメー 夕 (low-to medium-energy general-purpose: LMEGP) を装着したSymbiaT2 (Siemens Healthcare)を使用し た、マトリックスサイズは $128 \times 128$, ピクセルサイズ は $3.3 \mathrm{~mm}$, 収集方式は $180^{\circ}$ 対向検出器による円軌道 $360^{\circ}$ 連続回転収集, 投影デー夕数は 120 方向, 3 min/cycle の 40 分収集を行った. エネルギーウィン ドウは $159 \mathrm{keV} \pm 10.5 \%$ とした。減弱補正用の低線量 CT の撮像条件は, X 線管電圧 : $130 \mathrm{kV}, \mathrm{X}$ 線管電流 : CT-AEC (quality reference $\mathrm{mA}$ second : $50 \mathrm{mAs}$ ), X 線管回転速度 : $0.8 \mathrm{~s} /$ rotation, コリメーション : 2.5 $\mathrm{mm} \times 2$ 列, スライス厚 : $5 \mathrm{~mm}$, ピッチファクタ : 0.95 とした。

画像再構成方法は FBP 法および OSEM $\mathrm{RR}_{\mathrm{R}}$ 法を用い
た.FBP 法には前処理フィルタとして Butterworth フィルタ (次数: 8 , 遮断周波数: $0.45 \mathrm{cycles} / \mathrm{cm}$ ) を使 用した. OSEM $\mathrm{RR}_{\mathrm{R}}$ 法はサブセット数を 6 , イタレー ション回数を 15 とし, 後処理フィルタとして Gaussian フィルタ (FWHM : $6.6 \mathrm{~mm}$ )を使用した ${ }^{11)}$. 減弱補正には Chang 法と X 線 CT を用いた方法 (CT attenuation correction: CTAC)を用いた. Chang 法に おける線減弱係数 ( $\mu$ 值)の設定は, 散乱線補正なしの 場合はプールファントムを用いた事前実験により最適 化した值, $0.09 \mathrm{~cm}^{-1}$ を用い, 散乱線補正ありの場合は 理論值より $0.146 \mathrm{~cm}^{-1}$ とした。なお, CTACは $\mathrm{OSEM}_{\mathrm{RR}}$ 法にのみ使用した。散乱線補正には Multi energy window $(\mathrm{MEW})$ 法を用い, メインウィンドウ の両端 7\%をサブウィンドウに設定した ${ }^{12}$.

\section{1-2 ファントム評価}

\section{1-2-1 ファントムデータ}

線条体ファントムには DaT1308 型(NMP ビジネス サポート株式会社)を使用した。ファントムの放射能 濃度は 8:4:1 になるよう ${ }^{123} \mathrm{I}$ 水溶液を右線条体に $40.36 \mathrm{kBq} / \mathrm{mL}$, 左線条体に $20.25 \mathrm{kBq} / \mathrm{mL}$, 脳実質 (バックグラウンド)部分に $4.96 \mathrm{kBq} / \mathrm{mL}$ を封入した. ファントムデータは, 40 分収集データから時相の異な る 30 分収集デー夕を 5 セット (0〜30 分, 3〜33 分, 5 35 分, 7 37 分, 10 40 分) 作成し画像再構成を 行った。画像再構成方法の組み合わせは, (1) FBP,

(2) $\mathrm{FBP}+\mathrm{Chang}$, (3) $\mathrm{FBP}+\mathrm{Chang}+\mathrm{SC}$, (4) $\mathrm{OSEM}_{\mathrm{RR}}$, (5) $\mathrm{OSEM}_{\mathrm{RR}}+$ Chang, (6) OSEM $\mathrm{RR}_{\mathrm{RR}}+\mathrm{Chang}+\mathrm{SC}$, (7) $\mathrm{OSEM}_{\mathrm{RR}}+$ $\mathrm{CTAC}+\mathrm{SC}$, 計 7 種類とした。

\section{1-2-2 評価項目}

各ファントムデータから SBR を算出し, 各画像再 構成デー夕の定量性を評価した. SBRの算出には Tossici-Bolt らが報告した方法 ${ }^{5}$ (Tossici-Bolt 法)を採 用した解析ソフトウェアDaTview (日本メジフィジッ クス株式会社)を使用した. Tossici-Bolt 法による SBRは, 線条体に設定した関心領域 (region of interest: ROI) および立体的関心領域 (volume of interest; VOI) とバックグラウンドとの比により求める. 算出 式を次に示す。

$\mathrm{SBR}=\left(1 / V_{s}\right)\left\{C t_{\text {VOI }} / C r-V_{\text {VOI }}\right\}$

$V s$ ：線条体体積

$C t_{V O I}$ : 線条体 VOI の総カウント

$C r$ : 参照領域(脳全体)の単位体積当たりのカウント

$V_{V O I}$ : 線条体 VOI の体積

各種再構成データごとに算出した SBR の 5 回平均 
Table 1 Clinical diagnosis of subjects

\begin{tabular}{cccc}
\hline \hline NB groups & \multicolumn{2}{c}{ DB groups } \\
\hline Alzheimer's disease & 2 & Parkinson's disease & 22 \\
Drug-induced Parkinsonism & 2 & Progressive supranuclear palsy & 4 \\
Essential tremor & 1 & Multiple system atrophy & 3 \\
Wilson disease & 1 & Dementia with Lewy bodies & 3 \\
Healthy control & 2 & & \\
\hline
\end{tabular}

值を右，左それぞれ $\mathrm{SBR}_{\mathrm{R}}, \mathrm{SBR}_{\mathrm{L}}$, 左右平均值を $\mathrm{SBR}_{\mathrm{M}}$ とし, 画像再構成方法の違いによる SBR の変化を評 価した。

\section{1-3 臨床評価}

\section{1-3-1 患者背景および評価データ}

対象は診断目的で ${ }^{123}$ I-FP-CIT SPECT を実施した臨 床 40 症例 (男性：17 例, 女性 : 23 例, 平均 69 12 歳) で，パーキンソン病 (Parkinson's disease: PD) 22 例, 進行性核上性麻痺 (progressive supranuclear palsy: PSP) 4 例, 多系統萎縮症 (multiple system atrophy: MSA) 3 例, レビー小体型認知症 (dementia with Lewy bodies: DLB) 3 例, アルッハイマー病 (Alzheimer's disease: AD) 2 例，薬剤性パーキンソン症候群 (druginduced Parkinsonism: DIP) 2 例, 健常例 (healthy control) 2 例, 本態性振戦 (essential tremor: ET) 1 例, ウィルソン病(Wilson disease) 1 例である。この 40 症 例を ${ }^{123}$ I-FP-CIT SPECT の集積が正常集積を示すこと が予測される (normal binding: NB) 群と集積低下が予 測される (decreased binding: DB) 群に診断結果を基に 分類した ${ }^{413)}$ (Table 1). 分類は当院神経内科医師によ る診断結果を用いており， ${ }^{123}$ I-FP-CIT SPECT の集積 結果は考慮していない, なお, 本検討は当院倫理委員 会の承認を得たものであり, 患者の診断結果掞よび画 像デー夕の個人情報は本検討においてのみ扱うもので ある。

すべての患者に対して ${ }^{123}$ I-FP-CIT $167 \mathrm{MBq}$ を静脈 投与し, 投与後 3 時間後から撮像を行った。データ収 集後, 続けて頭部低線量 $\mathrm{CT}$ を撮像した。画像再構成 方法はファントム評価同様に, (1)FBP, (2)FBP+ Chang, (3) FBP+Chang+SC, (4) OSEM $\mathrm{RR}_{\mathrm{RR}}$, (5)OSEM $\mathrm{RR}_{\mathrm{R}}+$ Chang, (6) OSEM $\mathrm{RR}_{\mathrm{RR}}+$ Chang+SC, (7)OSEM $\mathrm{RR}_{\mathrm{R}}+\mathrm{CTAC}+$ $\mathrm{SC}$, 計 7 種類とした.

\section{1-3-2 診断能の評価}

各種再構成デー夕に対し，ファントム評価同様に患 者ごとの $\mathrm{SBR}\left(\mathrm{SBR}_{\mathrm{C}}\right)$ を算出し, $\mathrm{NB}$ 群と $\mathrm{DB}$ 群それぞ れの $\mathrm{SBR}_{\mathrm{C}}$ を比較した。診断能の評価には receiver operating characteristic analysis (ROC 解析) を用い
た. 解析ソフトウェアには Easy R を使用した ${ }^{14)}$. 患 者ごとの $\mathrm{SBR}_{\mathrm{C}}$ を入力, 診断結果 $(\mathrm{NB}$ 群または $\mathrm{DB}$ 群)を出力とし, ROC 曲線下の面積 (area under the curve: AUC) 值から診断能を再構成方法間で比較し た。 また, 再構成方法ごとの最適なカットオフ值は, ROC 曲線において感度と偽陽性率が共に最大となる ときの SBR とした。

\section{1-4 統計解析}

ファントム評価における $\mathrm{SBR}_{\mathrm{M}}$ ，また臨床評価にお ける $\mathrm{SBR}_{\mathrm{C}}$ の再構成方法間の比較は Tukey 法による多 重比較検定を行った. $\mathrm{SBR}_{\mathrm{C}}$ の NB 群と DB 群間の比 較はマン・ホイットニーのU 検定を行った．各検定 に扔ける統計学的有意水準は, 危険率 5\%未満とした。

\section{2. 結 果}

\section{2-1 ファントム評価}

再構成方法ごとの $\mathrm{SBR}_{\mathrm{R}}, \mathrm{SBR}_{\mathrm{L}}, \mathrm{SBR}_{\mathrm{M}}$ の結果を Table 2 に示す. $\mathrm{SBR}_{\mathrm{R}}, \mathrm{SBR}_{\mathrm{L}}$ ともに $\mathrm{AC}$ と $\mathrm{SC}$ を加え ることでSBR は上昇する傾向を示したＦBP 法にお ける $\mathrm{SBR}_{\mathrm{M}}$ は, FBP で 7.38 \pm 0.07 , FBP+Chang で $9.42 \pm$ 0.09, FBP+Chang+SCで $11.36 \pm 0.07$ となり，AC およ び $\mathrm{SC}$ を加えることで $\mathrm{SBR}_{\mathrm{M}}$ は有意に上昇した。

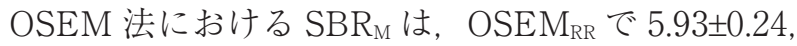
OSEM $_{R R}+$ Chang で 8.24 \pm 0.30 , OSEM RR $_{R}+$ Chang+SC で $10.01 \pm 0.23, \mathrm{OSEM}_{\mathrm{RR}}+\mathrm{CTAC}+\mathrm{SC}$ で 7.92 \pm 0.14 となり, $\mathrm{FBP}$ 法と同様に $\mathrm{OSEM}_{\mathrm{RR}}$ 単独に比べ, AC および $\mathrm{SC}$ を加えることで $\mathrm{SBR}_{\mathrm{M}}$ は有意に上昇した。また， $\mathrm{AC}$ はChang 法を用いた方がCTAC と比較して $\mathrm{SBR}_{\mathrm{M}}$ は 有意に高值を示した。 FBP 単独と OSEM $\mathrm{OR}_{\mathrm{R}}$ 単独の $\mathrm{SBR}_{\mathrm{M}}$ に有意差が認められた。

\section{2-2 臨床評価}

再構成方法ごとの $\mathrm{SBR}_{\mathrm{C}}$ の分布を $\mathrm{NB}$ 群と $\mathrm{DB}$ 群ご とに Figure に示す. $\mathrm{SBR}_{\mathrm{C}}$ の平均值は $\mathrm{FBP} て ゙ \mathrm{NB}$

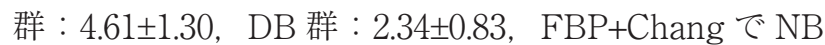
群 : $6.32 \pm 1.27$, DB 群 : $3.74 \pm 0.86$, FBP+Chang+SC で

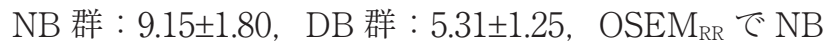


Table 2 Comparison of $\mathrm{SBR}_{\mathrm{L}}, \mathrm{SBR}_{\mathrm{R}}$ and $\mathrm{SBR}_{\mathrm{M}}$

\begin{tabular}{|c|c|c|c|c|}
\hline Combinations of reconstruction & $\mathrm{SBR}_{\mathrm{R}}($ mean $\pm \mathrm{SD})$ & $\mathrm{SBR}_{\mathrm{L}}($ mean $\pm \mathrm{SD})$ & \multicolumn{2}{|c|}{$\mathrm{SBR}_{\mathrm{M}}($ mean $\pm \mathrm{SD})$} \\
\hline FBP & $9.70 \pm 0.07$ & $5.07 \pm 0.08$ & \multicolumn{2}{|c|}{$7.38 \pm 0.07$} \\
\hline FBP+Chang & $12.00 \pm 0.07$ & $6.84 \pm 0.14$ & \multicolumn{2}{|l|}{$9.42 \pm 0.09$} \\
\hline $\mathrm{FBP}+\mathrm{Chang}+\mathrm{SC}$ & $14.76 \pm 0.12$ & $7.96 \pm 0.12$ & \multicolumn{2}{|l|}{$11.36 \pm 0.07$} \\
\hline $\mathrm{OSEM}_{\mathrm{RR}}$ & $8.21 \pm 0.25$ & $3.64 \pm 0.25$ & \multicolumn{2}{|l|}{$5.93 \pm 0.24$} \\
\hline $\mathrm{OSEM}_{\mathrm{RR}}+$ Chang & $10.89 \pm 0.33$ & $5.59 \pm 0.28$ & \multicolumn{2}{|l|}{$8.24 \pm 0.307$} \\
\hline $\mathrm{OSEM}_{\mathrm{RR}}+$ Chang $+\mathrm{SC}$ & $13.54 \pm 0.34$ & $6.48 \pm 0.21$ & $10.01 \pm 0.23$ & \multirow[t]{2}{*}{ n.s. } \\
\hline $\mathrm{OSEM}_{\mathrm{RR}}+\mathrm{CTAC}+\mathrm{SC}$ & $11.21 \pm 0.14$ & $4.62 \pm 0.16$ & $7.92 \pm 0.14]$ & \\
\hline
\end{tabular}

The $\mathrm{SBR}_{\mathrm{M}}$ was not significantly different between $\mathrm{OSEM}_{\mathrm{RR}}+$ Chang and $\mathrm{OSEM}_{\mathrm{RR}}+\mathrm{CTAC}+\mathrm{SC}$. Without that, the $\mathrm{SBR}_{\mathrm{M}}$ of all combinations of reconstruction showed significantly difference. n.s.: not significant

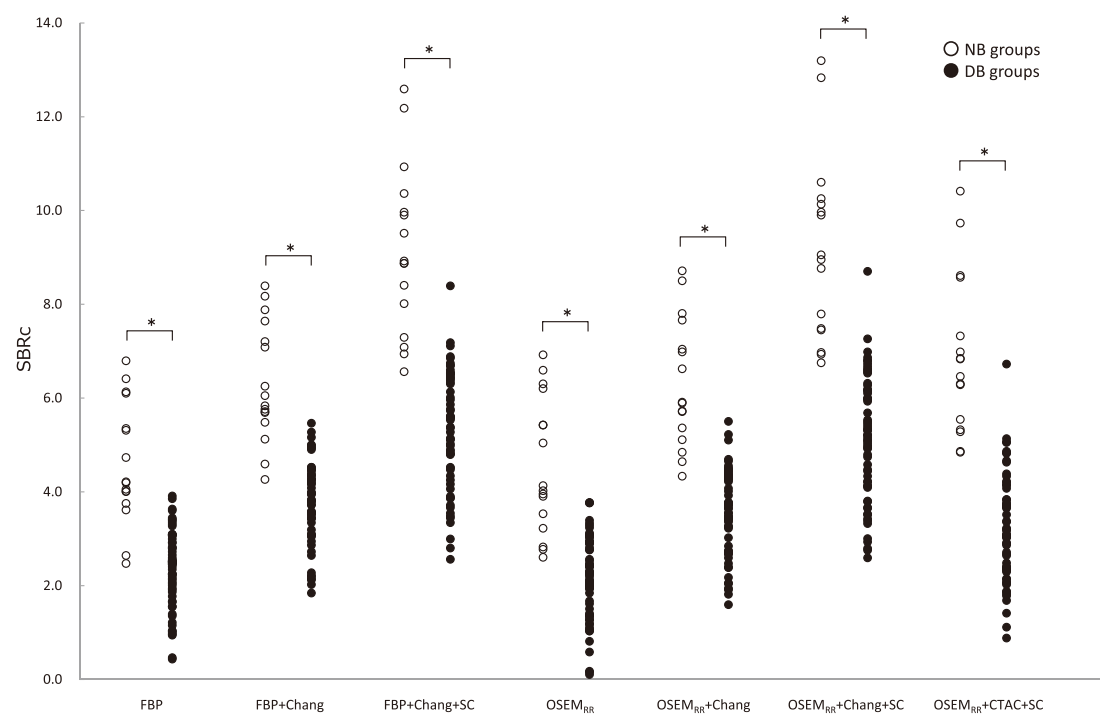

Figure Comparison of $\mathrm{SBR}_{\mathrm{C}}$ between the normal binding (NB) groups and decreased binding (DB) groups. The $\mathrm{SBR}_{\mathrm{C}}$ of all combinations of reconstruction in $\mathrm{NB}$ groups were significantly higher than those in DB groups $(*: P<0.05)$.

群 : 4.55 \pm 1.45 , DB 群 : $2.15 \pm 0.90, \quad$ OSEM $_{R R}+$ Chang で $\mathrm{NB}$ 群 : $6.30 \pm 1.36$, DB 群 : $3.54 \pm 0.91, \mathrm{OSEM}_{\mathrm{RR}}+$ Chang+ $\mathrm{SC}$ で NB 群 : $9.19 \pm 1.97$, DB 群 : 5.12 $\pm 1.32, \mathrm{OSEM}_{\mathrm{RR}}+$ CTAC+SC で NB 群 : $6.89 \pm 1.68$, DB 群 : $3.21 \pm 1.13$ と なった. $\mathrm{SBR}_{\mathrm{C}}$ の平均值はすべての再構成方法におい て NB 群と DB 群に有意差が認められた。FBP 法に ついては, FBP 単独に比べて $\mathrm{AC}$ および $\mathrm{SC}$ を加える ことで $\mathrm{SBR}_{\mathrm{C}}$ の分布は上昇し, 平均值に有意差が認め られた。 OSEM $\mathrm{RR}_{\mathrm{R}}$ 法についても同様に, OSEM $\mathrm{RR}_{\mathrm{R}}$ 単独 に比べて $\mathrm{AC}, \mathrm{SC}$ を加えることで $\mathrm{SBR}_{\mathrm{C}}$ の分布は上昇 し，平均值に有意差が認められた。また， $\mathrm{AC} は$ Chang 法を用いた方が CTAC と比較して $\mathrm{SBR}_{\mathrm{C}}$ の平 均值は有意に高值を示した。 FBP 単独と OSEM $\mathrm{OR}_{\mathrm{R}}$ 単 独の $\mathrm{SBR}_{\mathrm{C}}$ の平均值に有意差は認められなかった。

再構成方法ごとの ROC 解析の結果を Table 3 に示 す. $\mathrm{AUC}$ 值は, 各再構成方法で有意差はみられな
かったが，FBP 法掞よび $\mathrm{OSEM}_{\mathrm{RR}}$ 法ともに AC や SC を加えることで高值となる傾向を示した，また，各再 構成方法のカットオフ值は, FBP で 3.67, FBP+ Chang で 5.09, FBP+Chang+SC で 6.88, OSEM RR で

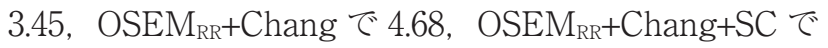
6.94, $\mathrm{OSEM}_{\mathrm{RR}}+\mathrm{CTAC}+\mathrm{SC}$ で 4.85 を示した.

\section{3. 考 察}

${ }^{123}$ I-FP-CIT SPECT による鑑別診断は, 視覚評価に 加えて定量評価が重要である。画質や定量性は，画像 再構成方法によって大きく変化するため, これらの影 響を評価することは重要な意味を持つと考える，本検 討ではファントムと臨床デー夕を用い, 画像再構成方 法が定量指標である SBR と診断能に与える影響を評 価した. SBR は画像再構成方法ごとに変化し，AC と SC を加えることで有意に上昇した(Table 2, Figure). 
Table 3 The AUC, sensitivity, specificity and cut-off values obtained by ROC analysis

\begin{tabular}{lcccc}
\hline \hline Combinations of reconstruction & AUC & Sensitivity & Specificity & $\begin{array}{c}\text { Cut off } \\
\text { value }\end{array}$ \\
\hline FBP & 0.96 & 0.92 & 0.95 & 3.67 \\
FBP+Chang & 0.98 & 0.93 & 0.95 & 5.09 \\
FBP+Chang+SC & 0.99 & 0.96 & 0.96 & 6.88 \\
\hline OSEM $_{\mathrm{RR}}$ & 0.96 & 0.85 & 0.95 & 3.45 \\
OSEM $_{\mathrm{RR}}+$ Chang & 0.98 & 0.96 & 0.94 & 4.68 \\
OSEM $_{\mathrm{RR}}+$ Chang+SC & 0.99 & 0.94 & 0.95 & 6.94 \\
OSEM $_{\mathrm{RR}}+\mathrm{CTAC}+\mathrm{SC}$ & 0.98 & 0.96 & 0.93 & 4.85 \\
\hline
\end{tabular}

The AUC value of all combinations of reconstruction did not show significantly difference.

また，統計学的な有意差は認められなかったが, AC と SC を行うことで AUC 值は向上する傾向にあり， 感度と特異度についても高值を示した(Table 3).

ファントム評価では画像再構成方法が定量性に与え る影響を評価した。一般に ACでは，減弱が予測され る範囲に対し補正係数を乗じることで補正が行われ る. 本検討では AC を行うことでファントム深部の減 弱されたカウント $\left(C t_{V O I}\right)$ が補正され, $\mathrm{SBR}_{\mathrm{M}}$ が上昇し たと考えられる。 また, Chang 法と CTAC を比較す ると $\mathrm{SBR}_{\mathrm{M}}$ に有意差が認められた(Table 2). Chang 法は基本的に均一吸収体を仮定しており, 減弱補正工 リアに対し一定の $\mu$ 值を用いて補正を行うものであ る。一方, CTACはCT データから得られるピクセル ごとの CT 值から ${ }^{123} \mathrm{I} の \gamma$ 線エネルギーに応じた $\mu$ 值 を算出して補正を行うものである。また, 減弱補正工 リアの設定には, Chang 法では闇值法を用いており， 頭皮を含むように輪郭抽出を行うことでエリア設定す るのに対し，CTAC は輪郭設定の必要はなく, FOV 内全てが補正エリアとなり得る。このようにChang 法と CTAC の補正原理の違いや輪郭抽出の再現性の 違いが $\mathrm{SBR}_{\mathrm{M}}$ に影響を与えたと考えられる。

一方，SCを行うことで $\mathrm{SBR}_{\mathrm{M}}$ は有意に高值を示し た(Table 2).SCでは測定データから散乱線成分を除 去することで線条体と参照領域のコントラストが向上 し， $\mathrm{SBR}_{\mathrm{M}}$ が上昇したと考えられる。林らは，脳血流 SPECTにAC，SC を用いることでコントラストが向 上したと報告している ${ }^{15)}$ 。またItoらは, 脳血流 SPECTにおいてSCを用いることで局所脳血流量測 定の定量性が向上したと報告している ${ }^{16)}$. したがって $\mathrm{AC}$ および SC は, SPECT の信号雑音比 (signal-noise ratio: $\mathrm{S} / \mathrm{N}$ 比) を改善すると考えられる. 本検討にお

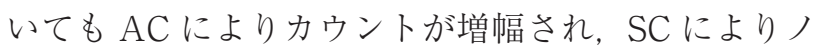
イズが除去されたことで SBR が上昇する結果となっ た。 ${ }^{123}$ I-FP-CIT SPECT において AC と SC は定量性 に影響を与える重要なパラメータといえる。
$\mathrm{FBP}$ 法とコリメータ開口補正を構造した OSEM $\mathrm{OSR}_{\mathrm{RR}}$ 法の $\mathrm{SBR}_{\mathrm{M}}$ に有意差が認められたが(Table 2)，ACや $\mathrm{SC}$ を加えることによる $\mathrm{SBR}_{\mathrm{M}}$ 変化に比べると，その 差は軽度であった，岡田らは，コリメー夕開口補正に より脳深部にある構造物の分解能および定量性が改善 されると報告しているが ${ }^{17)}$ ，本検討に扔ける定量性の 改善は認められなかった。 その要因としてフィルタ効

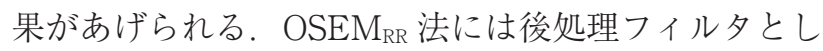
てGaussian フィルタを使用した。岡田らが使用した Butterworth フィルタが高周波成分を遮断するのに対 し, Gaussian フィルタは信号全体に対して平滑化を行 うため, フィルタ効果がコリメータ開口補正の効果を 打ち消す方向に働いた可能性があると考えられる ${ }^{11}$. また, 本研究で使用した Tossici-Bolt 法は, 線条体を 大きく囲んだVOIを用いることで, 部分容積効果の

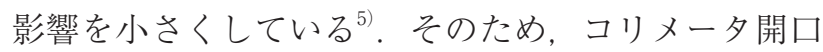
補正の効果が VOI 内に内包され，SBRへの影響が低 減されたと考える。

臨床評価ではファントム評価同様に画像再構成方法 が定量性に与える影響を検討し, 更に診断能と再構成 方法との関係を評価した。診断結果より分類された $\mathrm{NB}$ 群と $\mathrm{DB}$ 群それぞれの $\mathrm{SBR}_{\mathrm{C}}$ の平均值には，すべ ての再構成方法において有意差が認められた (Figure)。つまり ${ }^{123}$ I-FP-CIT SPECT の定量評価を行 うことで, 再構成方法に関係なく正常集積と集積低下 の鑑別が可能であることが確認された。 また，画像再 構成方法の違いによる $\mathrm{SBR}_{\mathrm{C}}$ の平均值は $\mathrm{FBP}$ 法, $\mathrm{OSEM}_{\mathrm{RR}}$ 法それぞれ単独での再構成に対して, AC と $\mathrm{SC}$ を加えることで有意に上昇し，ファントム評価と 同様の結果が得られた。したがって，臨床評価におい ても ACと SC はSBRに影響を与える重要なパラ メータといえる。一方で FBP 法と OSEM $\mathrm{RR}_{\mathrm{RR}}$ 法の $\mathrm{SBR}_{\mathrm{C}}$ の平均值に有意差は認められなかった。臨床評 価では，ファントムと異なり症例間差が大きく, Tossici-Bolt 法を用いた場合, シルビウス裂や脳室が 
参照領域や線条体 VOI 内に含まれることがある。こ れらが定量值に影響を与え, コリメー夕開口補正の効 果を低減させたと考える。

ROC 解析において AUC 值は, 各再構成方法で有意 差はみられなかったが，FBP 法抒よび OSEM $\mathrm{OR}_{\mathrm{RR}}$ 法と もに AC S SC を加えることで高值となる傾向を示し た。診断能に関する報告では, FBP 法およびコリメー 夕開口補正を構造した OSEM 法にそれぞれ AC と SC を加えることで視覚的な画質と診断能の向上が得られ たことが報告されている ${ }^{13)}$. 本研究も同様の結果を示 しており， ${ }^{123}$ I-FP-CIT SPECT における画像再構成に は AC および SC が有用であると考えられる。

一方, SBRのカットオフ值は画像再構成法や補正の 有無により大きく変化した (Table 3)。これは再構成 パラメータの組合せにより NB 群と DB 群の SBR が 変化したためであり，SBRを臨床に用いる際には使用 する画像再構成方法に対応したカットオフ值の算出が 必要であるといえる.

本研究では, 補正の有無によるSBRの変化を評価 するため, ファントムの放射能濃度をある程度高く設 定したが，低濃度では統計的学的変動が大きくなる可 能性がある。また, 臨床評価では SBR と診断能との 関係に焦点を当てて評価しており, 左右線条体比の評 価や画像の視覚評価と診断能との関係については評価 していない.今後は画像の視覚評価と診断能の検証も 行う必要がある。また，本研究は限定された施設と装
置で行った. SPECTの画質や定量性は画像再構成条 件のみならず，使用する装置やアルゴリズムによって 変化するため ${ }^{18)}$, 多施設による評価が必要と考える.

\section{4. 結 語}

本研究では ${ }^{123}$ I-FP-CIT SPECT において, 異なる画 像再構成方法による定量性と診断能について, ファン トムデー夕および臨床デー夕を用いて検討した。 ${ }^{123} \mathrm{I}-$ FP-CIT SPECT の定量評価により, 画像再構成方法に 関係なく正常集積と集積低下の鑑別が可能であった。 また, ファントム評価, 臨床評価ともに画像再構成方 法ごとに SBR は変化し, AC と SC を加えることで SBR は上昇した。 ROC 解析による診断能評価では各 再構成方法に有意差は認められなかったが, AC と SC を加えることで診断能が高くなる傾向を示した. ${ }^{123} \mathrm{I}$ FP-CIT SPECT の画像再構成には AC およびSC の使 用が有用である可能性が高く, 使用する画像再構成方 法に対応したカットオフ值の算出が必要である.

\section{謝 辞}

本稿を終えるにあたり，ご指導いただきました当院 神経内科医師ならびに放射線技術部諸氏に厚く御礼申 し上げます．

なお, 本論文の内容は第 71 回日本放射線技術学会 総会学術大会 (2015 年, 横浜)において発表した。

\section{参考文献}

1) Booij J, Tissingh G, Boer GJ, et al. [123I] FP-CIT SPECT shows a pronounced decline of striatal dopamine transporter labelling in early and advanced Parkinson's disease. J Neurol Neurosurg Psychiatr 1997; 62(2): 133-140.

2) McKeith I, O'Brien J, Walker Z, et al. Sensitivity and specificity of dopamine transporter imaging with 123I-FP-CIT SPECT in dementia with Lewy bodies: a phase III, multicentre study. Lancet Neurol 2007; 6(4): 305-313.

3) Benamer TS, Patterson J, Grosset DG, et al. Accurate differentiation of parkinsonism and essential tremor using visual assessment of [123I] -FP-CIT SPECT imaging: the [123I]-FP-CIT study group. Mov Disord 2000; 15(3): 503-510.

4) 日本核医学会. 日本脳神経核医学研究会編. イオフルパ ン診療ガイドライン第 1 版. 2014; 3-17.

5) Tossici-Bolt L, Hoffmann SM, Kemp PM, et al. Quantification of [123I]FP-CIT SPECT brain images: an accurate technique for measurement of the specific binding ratio. Eur J Nucl Med Mol Imaging 2006; 33(12): 1491-1499.

6) Darcourt J, Booij J, Tatsch K, et al. EANM procedure guidelines for brain neurotransmission SPECT using (123) Ilabelled dopamine transporter ligands, version 2. Eur J Nucl Med Mol Imaging 2010; 37(2): 443-450.

7) Djang DS, Janssen MJ, Bohnen N, et al. SNM practice guideline for dopamine transporter imaging with 123Iioflupane SPECT 1.0. J Nucl Med 2012; 53(1): 154-163.

8) Koch W, Hamann C, Welsch J, et al. Is iterative reconstruction an alternative to filtered backprojection in routine processing of dopamine transporter SPECT studies? J Nucl Med 2005; 46 (11): 1804-1811.

9) Bienkiewicz M, Gorska-Chrzastek M, Siennicki J, et al. Impact of CT based attenuation correction on quantitative assessment of DaTSCAN (123I-Ioflupane) imaging in diagnosis of extrapyramidal diseases. Nuclear Med Rev 2008; 11(2): 53-58.

10) Dickson JC, Tossici-Bolt L, Sera $T$, et al. The impact of reconstruction method on the quantification of DaTSCAN images. Eur J Nucl Med Mol Imaging 2010; 37(1): 23-35.

11）松友紀和, 田中崇史, 長木昭男, 他. シミュレーション データを用いた逐次近似画像再構成法に対するノイズ除 去処理の検証. 日放技学誌 2014; 70(8): 773-783.

12) Ogawa K, Ichihara T, Kubo A. Accurate scatter correction in single photon emission CT. Ann Nucl Med Sci 1994; 7: 145150 .

13) Matsutomo N, Nagaki A, Yamao F, et al. Optimization of iterative reconstruction parameters with 3-dimensional resolution recovery, scatter and attenuation correction in ${ }^{123}$ I-FP-CIT SPECT. Ann Nucl Med 2015; 29(7): 636-642. 
14) Kanda Y. Investigation of the freely available easy-to-use software 'EZR' for medical statistics. Bone Marrow Transplant 2013; 48(3): 452-458.

15）林万寿夫, 福村勝典, 浅津 輝, 他. 散乱 ·減弱補正法を 用いた局所脳血流量測定法の検討。核医技 1997; 17(1): 2-9.

16) Ito $H$, Iida $H$, Kinoshita $T$, et al. Effects of scatter correction on regional distribution of cerebral blood flow using I-123-IMP and SPECT. Ann Nucl Med 1999; 13(5): 331-336.
17）岡田真美, 林万寿夫, 辻 久志, 他. コリメー夕開口補正 OSEM 再構成法の局所脳血流量定量への応用. 日放技学 誌 2012; 68(5): 573-583.

18）松友紀和，古谷洋晃，山尾太一郎，他．SPECT デー夕評価 用ディジタルファントムを用いた異なる処理装置間の OS-EM 再構成アルゴリズムの比較。日放技学誌 2008; 64 (11): 1361-1368. 